\title{
JUCER \\ doi: 10.20885/ijcer.vol2.iss2.art1 \\ Development of Guided Inquiry Based Work Sheet with Class and Laboratory Activity on Chemical Bonding Topic in Senior High School
}

\author{
Zammiluni $^{\mathrm{a}}$, Allizar Ulianas ${ }^{\mathrm{a}}$, Mawardia,* \\ ${ }^{a}$ Department of Chemistry, Universitas Negeri Padang \\ *Corresponding author: mawardianwar@fmipa.unp.ac.id \\ zammiluni01@gmail.com \\ alizar_chem@yahoo.co.id
}

\begin{abstract}
This research produced a teaching material in the form Work Sheet (LKPD) based guided inquiry which involves 3 levels of chemical phenomena namely macroscopic, sub-microscopic and symbolic. The worksheet was created using Plomp model and using guided inquiry learning cycle consisting of orientation, exploration, concept formation, application, and closure. This LKPD has been tested validity, practicality, and effectiveness. The validity test gives the result of the kappa moment of 0.83 with the category of very high. Analysis of practicality in one-to-one, small group, and field test stage showed the value of $0.80,0.76$, and 0.70 with all three values in the high category. Effectiveness test seen from student's learning outcome before and after using LKPD obtained gain score is 0.76 in the high category and average activity of students is $86.3 \%$ at every meeting. The results showed that, worksheet using the Plomp model which has been produced are valid, practical, and effective
\end{abstract}

Keywords: Guided inquiry, chemical bonding, validity, practicality, effectiveness

\section{INTRODUCTION}

The study of matter and its accompanying changes is called chemistry [1]. American Chemical Society states that chemistry is a laboratory science, meaning that the concepts contained in the chemistry cannot be studied effective without doing laboratory activities [2]. Chemistry is generally a difficult subject for most students and is related to the structure of matter [3].

The subjects in chemistry in high school consisted of submicroscopic (abstract), macroscopic (visible with senses), and symbolic (symbolic) material [4]. For example, chemical bonding material is an example of material that is abstract and far from everyday experience, for example: cannot see atoms, structures, and how to react with other atoms [5].

Based on the results of interviews with 5 chemistry teachers and 20 questionnaires to students in three Senior High Schools Padang showed that students had difficulties in understanding chemical bonding material especially in depiction of structure Lewis, bond formation, types of chemical bonds. In the process of learning, teachers using teaching materials that are books and Work sheet (LKPD). The results of preliminary analysis indicate that $55 \%$ of students stated that LKPD used is generally still in the category of doing rhetorical exercise questions, introduction of formulas, introducing the terms through practice, but not to find their own concepts. Laboratory activities and the use of learning models within LKPD does not yet exist.

LKPD as a component of the learning system needs to be developed as well as its use in learning. Especially LKPD was based on curriculum 2013. The use of LKPD will not give satisfactory results without the use of instructional model in the learning process. Learning in the curriculum of 2013 prioritizes a scientific approach. One of the learning models that can be used is the model of learning of inquiry [6,7]. Thus, teachers need to seek an appropriate learning in improving the activities or activities of students and directing students in building their knowledge through the process of investigation.

Based on previous research that has been done by Bilgin and Myers showed that students who learn by using guided inquiry strategy more easily understand and understand the concept of lesson and improve the effectiveness of interaction, team building, learning, and interest through group work which is highly structured $[8,9]$. Based on this research has been done to develop teaching materials in the form of guided inquiry-based work sheet (LKPD) under the heading "Development Of Student Work Sheet 
(LKPD) Based Guided Inquiry With Activities Classes And Laboratories On The Materials Chemical Bonding Classes X SMA/MA.

\section{METHOD}

Type of research used is (Research and Development). The development model used in this research is the Plomp model developed by Tjeerd Plomp which consists of three stages: (1) preliminary research, (2) prototyping stage, and (3) assessment phase [10]. LKPD based guided inquiry is validated by 4 lecturers and two chemistry teachers and tested to thirty-five students of class X MIPA SMA Negeri 5 Padang even semester of academic year 2016/2017.

In the initial investigation stage, a needs analysis consisted of teacher and learner analysis and context analysis consisting of curriculum analysis and concept analysis. In the prototyping stage, LKPD design is based on guided inquiry on chemical bonding material, validation of LKPD by validator, one to one evaluation and small group evaluation conducted on students with different capabilities (high ability, medium and low) to determine the level of practice.

In the assessment phase there is a test of practicability and effectiveness test. Practical LKPD based guided inquiry is seen from the questionnaire response of students and teacher response questionnaire. While the effectiveness of LKPD based guided inquiry is seen from the learning outcomes and learning activities of students.

This study used a validation sheet instrument aimed at lecturers of Postgraduate Chemistry and questionnaire responses of teachers and students. In addition it is also used effectiveness test instruments consist of test results and observation sheet learner's activities. The validation sheet is used to assess LKPD from four aspects (content, construct, language, and graphical components). Questionnaire used determine the level of practice using LKPD based inquiry guided in the learning process. Instruments of effectivity used to determine the learning outcomes and observation sheet students activities.

Data analysis used for validity and practicality test using kappa moment $(\mathrm{k})$ as reported by Boslaugh, Sarah and Paul A. as follows [11]:

$$
\text { moment kappa }(k)=\frac{P-P e}{1-P e}
$$

where, $k=$ The kappa moment indicates the validity of the product

$P=$ The realized proportion, calculated by the number of values given by the validator divided by the sum of the maximum value

$P e=$ The unrealized proportion is calculated by the sum of the maximum value minus the total number of validated entries divided by the maximum number of values.

Kappa moment category decision was show in Table 1.

TABLE 1. Moment Kappa Category (k)

\begin{tabular}{cc}
\hline Interval & Category \\
\hline $0,81-1,00$ & Very high \\
$0,61-0,80$ & High \\
$0,41-0,60$ & Medium \\
$0,21-0,40$ & Low \\
$0,01-0,20$ & Very low \\
$<0,00$ & No Valid \\
\hline
\end{tabular}

Analysis of students' understanding of the learning outcomes of students is determined using percentage approach as suggested by Kunandar as follows: [12]

where, $P=$ percentage of students' understanding

$$
P=\frac{F}{N} \times 100 \% \text {. }
$$

$F=$ scores gained

$N=$ maximum value 
While the analysis of the effectiveness of teaching materials on the cognitive enhancement of students is analyzed by using the $\mathrm{N}$-gain formula proposed by Hake as follows [13]:

$$
<\mathrm{g}>=\frac{\%<\text { post test }>-\%<\text { pre test }>}{100-\%<\text { pre test }>}
$$

where $\%<$ posttest $>=$ posttest class averages $\%<$ pretest $>=$ pretest class averages.

The magnitude of the average gain $\langle\mathrm{g}>$ is interpreted based on the criteria in Table 2 .

TABLE 2. Average Criteria of $\mathrm{N}$-gain

\begin{tabular}{cc}
\hline Limitations & Criteria \\
\hline$g \geq 0,7$ & High \\
$0,3 \leq g<$ & Medium \\
0,7 & \\
$g<0,3$ & Low \\
\hline
\end{tabular}

Furthermore activity analysis of the students is tested using the percentage approach as follows [12]:

$$
\% A=\frac{f}{x} \times 100 \%
$$

Where, $\% \mathrm{~A}=$ The percentage of active students in each activity

$f \quad=$ number of active students

$\mathrm{x}=$ the number of students present at the meeting

Student activity criteria according to Ridwan can be seen in Table 3 [14].

TABLE 3. Criteria Analysis Observation Sheet Student Activity

\begin{tabular}{ccc}
\hline $\begin{array}{c}\text { Percentage } \\
(\%)\end{array}$ & Category & $\begin{array}{c}\text { Criteria After } \\
\text { converted }\end{array}$ \\
\hline $81-100$ & Very high & Very effective \\
$61-80$ & High & Effective \\
$41-60$ & Medium & Effective enough \\
$21-40$ & Low & Less effective \\
$0-20$ & Very less & Ineffective \\
\hline
\end{tabular}

\section{RESULT AND DISCUSSION}

Preliminary Research

In the initial investigation phase, needs analysis and context analysis are conducted. Needs analysis consists of teacher needs analysis (interview) and needs analysis of students (questionnaire). Teacher needs analysis shows that students have difficulties in understanding the chemical bonding material that is the depiction of the Lewis structure, the formation of the bond, and the types of chemical bonds that are formed. In the learning process, teachers use teaching materials in the form of book packages and Student Work Sheets (LKPD). Student Work Sheets (LKPD) used do not involve all three levels of chemical representation and have not required students to find a concept of their own. LKPD is generally used by students to do the exercise questions. Analysis of the needs and problems of students showed that $55 \%$ of teaching materials owned by students used only to answer exercise questions. $50 \%$ Students say in the teaching materials there are questions that lead to understand chemical bonds. $65 \%$ of students said in studying chemical bonds should be accompanied by practicum activities. Result of requirement analysis students can be seen in Figure 1. 


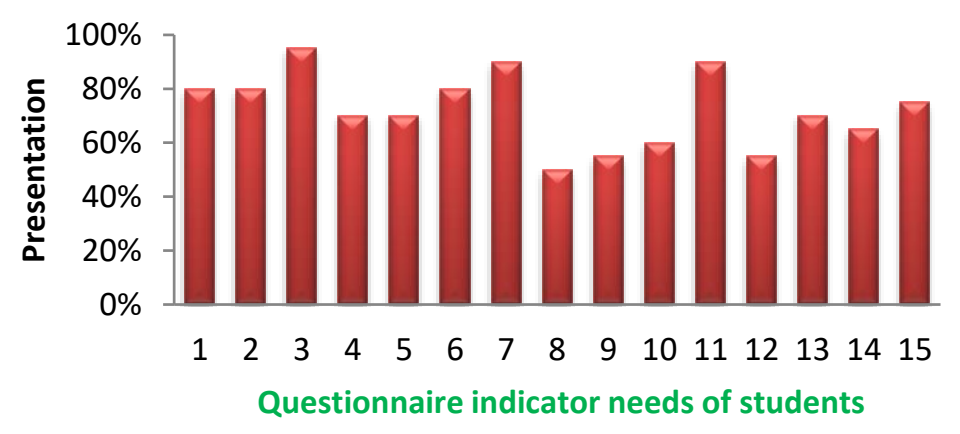

FIGURE1. Percentage of questionnaire needs of students.

The indicator of the questionnaire needs of students is shown in Table 4.

TABLE 4. Questionnaire indicator needs of students.

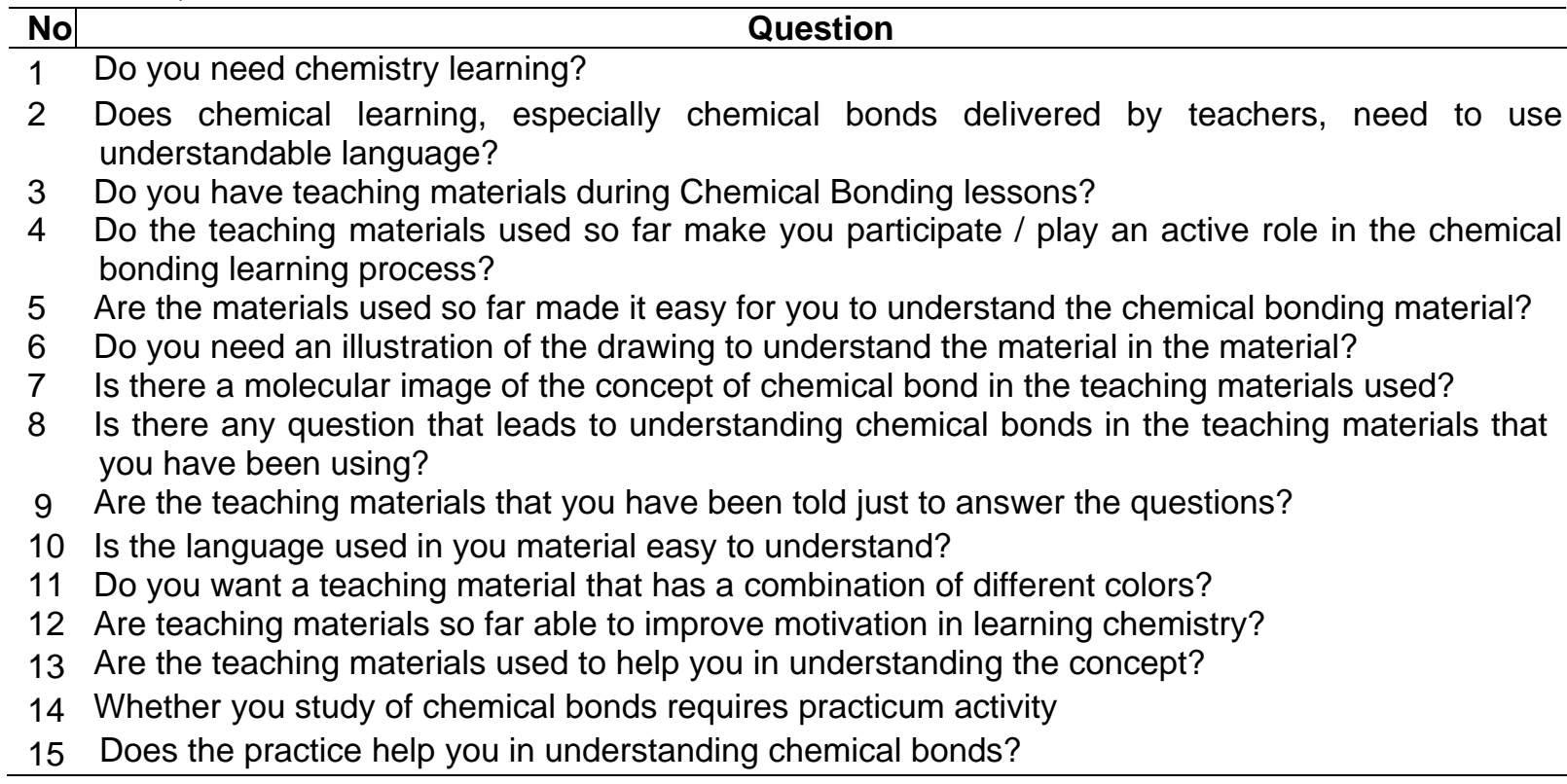

Context analysis consists of curriculum analysis and concept analysis. The curriculum analysis is Core Competence (KI), Basic Competence (KD) in the syllabus, and obtained some indicators of learning. From concept analysis, the main concepts in chemical bonding material are element stability, ionic bond, covalent bond, coordination covalent bond, metal bond, molecular shape and interaction between particles.

\section{Prototyping stage}

At this stage self-evaluation is performed using checklists, validation of LKPD by validator, one to one evaluation and small group evaluation conducted on students with different capabilities different (low, medium and high ability) to determine the level of practice.

Validity Test.

Guided inquiry-based LKPD is validated by validators performed to reveal the contents, constructs, language and graphical components of LKPD that have been designed. The results of the LKPD validity test are shown in Table 5. 
TABLE 5. Average LKPD validity test results

\begin{tabular}{llc}
\hline No & Aspect Assessed & Average $\boldsymbol{k}$ \\
\hline 1 & Content compound & 0,79 \\
2 & Construct compound & 0,78 \\
3 & Graphical compound & 0,86 \\
4 & Language compound & 0,89 \\
\hline \multicolumn{2}{l}{ Total } & $\mathbf{0 , 8 3}$ \\
\hline \multicolumn{2}{l}{ Categories of validity } & Very high \\
\hline
\end{tabular}

Based on the results of expert validation of LKPD on inquiry-based chemically based bonding material obtained validation LKPD analysis is valid with the category of very high. The validator assigns a valid value because the guided inquiry-based LKPD meets the criteria that correspond to its scoring tool (validation sheet). As Van den Akker states that validity refers to the level of design based on knowledge (content validity) and various components relating to each other (construct validity) [15].

\section{Practical Test of one to one and small group}

Practical test results through one to-one and small group tests can be seen in Table 6 .

TABLE 6. Results one to one evaluation dan small group

\begin{tabular}{llcc}
\hline No & Aspect Assessed & $\begin{array}{c}\text { Average } \boldsymbol{k} \\
\text { One to one evaluation }\end{array}$ & $\begin{array}{c}\text { Average } \boldsymbol{k} \\
\text { Small Group }\end{array}$ \\
\hline 1 & Ease of use & 0,88 & 0,75 \\
2 & Benefit of use & 0,80 & 0,88 \\
3 & Efficiency of usage & 0,67 & 0,67 \\
& time & 0,83 & 0,74 \\
\hline & Attractiveness & $\mathbf{0 , 8 0}$ & $\mathbf{0 , 7 6}$ \\
\hline Average & High & High \\
\hline
\end{tabular}

Based on the table 6, practical test results through one to-one and small group tests obtained average kappa moments from all aspects (ease of use, benefit of use, efficiency of usage time, and attractiveness) assessed were 0.80 and 0.76 with high category. This suggests that the guided inquiry based LKPD with class and laboratory activity on the class X chemical bonding material that LKPD already has an attractive look. The presentation of materials and the language used has been good and easy to understand by students, and has included questions that can lead students to discover and understand the concept of chemical bonding material.

\section{Assessment phase}

\section{a. Practicality Test}

LKPD practical analysis of teacher response questionnaire and student response can be seen in Table 7 .

TABLE 7. LKPD Practical Assessment Data

\begin{tabular}{clcc}
\hline No & \multicolumn{1}{c}{$\begin{array}{c}\text { Aspect } \\
\text { Assessed }\end{array}$} & $\begin{array}{c}\text { Average value } \boldsymbol{k} \\
\text { student response } \\
\text { questionnaire }\end{array}$ & $\begin{array}{c}\text { Average Value } \mathbf{k} \text { teacher } \\
\text { response questionnaire }\end{array}$ \\
\hline 1 & Ease of use & 0,75 & 0,74 \\
2 & Benefit of use & 0,81 & 0,77 \\
3 & Efficiency of & 0,73 & 0,67 \\
& usage time & 0,78 & 0,67 \\
\hline & Attractiveness & $\mathbf{0 , 7 7}$ & $\mathbf{0 , 7 0}$ \\
\hline Average & High & High \\
\hline
\end{tabular}


Assessment of practicable LKPD based on inquiry is obtained by high category. From the result of that practice, this guided inquiry-based LKPD can be applied to the learning process in school.

b. Effectiveness Test

The effectiveness of the inquiry-based LKPD guided in this study was analyzed from the learning outcomes of students which can be seen in Table 8 and the learning activities of the students in Table 9.

TABLE 8. Student Learning Outcomes Data

\begin{tabular}{cc}
\hline Test & Average \\
\hline Pre tes & 32,7 \\
Post tes & 83,9 \\
N-Gain & 0,76 \\
\hline
\end{tabular}

Based on the $\mathrm{N}$-gain calculation obtained gain score of 35 students is 0.76 indicating that the increase of learning outcomes of students in the category of "High", in accordance with the criteria of Hake [13]. This is in line with those described by Bilgin and Myers the use of guided inquiry learning model is easier to understand the concept, can improve high order thingking and improve student learning outcomes, and provide meaningful learning $[8,9]$.

According to Table 9, the percentage of learner's activeness when using guided inquiry-based LKPD is $86.3 \%$, which means that students' activity is very effective. According to The College Board [16] learning by using guided inquiry will increase the learning activities of students because to find the concepts of students analyze the data by discussing with a group of friends and at the stage of confirmation of students to communicate the concept they have gained.

TABLE 9. Recapitulation of Observation Sheet Values Activity 35 Students

\begin{tabular}{|c|c|c|c|c|c|}
\hline \multirow[t]{2}{*}{ Activity } & \multicolumn{5}{|c|}{$\begin{array}{l}\text { Percentage (\%) } \\
\text { Meeting }\end{array}$} \\
\hline & $\mathrm{I}^{*}$ & $\|^{*}$ & $\mathrm{III}^{*}$ & $\mathrm{IV}^{* *}$ & $\mathrm{~V}^{*}$ \\
\hline Observe and analyze models & 88,6 & 85,7 & 97,1 & 71,4 & 100 \\
\hline $\begin{array}{l}\text { Discuss with the group to answer } \\
\text { key questions }\end{array}$ & 85,7 & 85,7 & 94,3 & - & 97,1 \\
\hline Answering pre-lab questions & - & - & - & 100 & \\
\hline $\begin{array}{l}\text { Ask the teacher to understand } \\
\text { the material }\end{array}$ & 51,4 & 57,1 & 85,7 & 74,3 & 62,9 \\
\hline $\begin{array}{l}\text { Respond to teacher questions / } \\
\text { statements }\end{array}$ & 57,1 & 80 & 57,1 & - & 60 \\
\hline $\begin{array}{l}\text { Doing practicum activities } \\
\text { Observe the results of the lab }\end{array}$ & - & - & - & 77,1 & - \\
\hline $\begin{array}{l}\text { and record the results of these } \\
\text { observations }\end{array}$ & - & - & - & 97,1 & - \\
\hline Doing the exercises & 100 & 100 & 100 & - & 100 \\
\hline Doing post-lab work & - & - & & 100 & - \\
\hline Make a conclusion & 100 & 100 & 100 & - & 100 \\
\hline Average & 80,5 & 84,8 & 89,0 & 86,7 & 86,7 \\
\hline $\begin{array}{l}\text { Average and } \\
\text { Category }\end{array}$ & \multicolumn{3}{|c|}{$86,3 \%$} & \multicolumn{2}{|c|}{$\begin{array}{c}\text { Very } \\
\text { Effective }\end{array}$} \\
\hline
\end{tabular}




\section{CONCLUSION}

Inquiry-based learning work sheet (LKPD) guided on chemical bonding material for high school students of SMA/MA level has a very high prevalence, high practicality and effective use in the learning process. Therefore LKPD can be used as a teaching material on chemical bond material class X / SMA SMA

\section{ACKNOWLEDGMENT}

We would like to thank the Department of chemistry Universitas Negeri Padang for his support in this research.

\section{REFERENCES}

1. R. Chang, General Chemistry: The Essential Concept Sixth Edition (Mc Graw Hill Higher Education, New York, 2011), pp.1.

2. American Chemical Society, ACS Guidelines and Recommendation for the Theaching of High School Chemistry (American Chemical Society, Washington, 2012), pp. 10.

3. G. Sirhan, Journal of TU SED. 4, 2, 2-20 (2007).

4. G. Chittleborough, D. F. Treagust, Chemistry Education Research and Practice. 8, 3, 274-292 (2007).

5. H. Özmen, Journal of TU SED. 13, 2, 147-159 (2004).

6. G. Dwi yanti, A. Suryatna, I. Taba, Development of Guided Inquiry-Based Student Lab Worksheet on the Making of Pineapple Flavoring. DOI: 10.1088/1742-6596/812/1/012074, 1 (2017).

7. S. Rahmiati, dan Mawardi., Proceedings of Academics World $28^{\text {th }}$ International Conference (Tokyo, Japan, 28 th March, 2016). 65. ISBN 978-93- 85973-72-7

8. I. Bilgin, Scientific Research and Essay. 4, 10, 1038-1046 (2009)

9. Myers, Monypenny, Trevathan, JLD. 5, 1, 12-22 (2012)

10.Plomp, and nieveen, Part A: Educational Design Research: An Introduction (Netherland Institute for Curriculum Development (SLO), Netherland, 2013), pp. 15.

11.Boslaugh, Sarah dan Paul, Statistics in a Nutshell, a desktop quick reference (O'reilly, Beijing, Cambridge, Famham, Köln, Sebastopol, Taipei, Tokyo, 2008), pp. 13.

12. Kunandar, Guru Profesional Implementasi Kurikulum Tingkat Satuan Pendidikan dan Sukses dalam Sertifikasi Guru (Raja Grafindo Persada, Jakarta, 2007).

13. Hake, Relationship of Individual Student Normalized Learning Gains in Mechanics with Gender, HighSchool Physics, and Pretest Scores on Mathematics and Spatial Visualization. 3 (2002).

14. Ridwan, Belajar Mudah Penelitian Untuk Guru-Karyawan dan Peneliti Pemula (Alfabeta, Bandung, 2009).

15.Van den Akker, Jan, Design Approaches and Tools in Education and Training (Springer Science Business Media, B.V, Dordrecht, 1999), pp. 10.

16. The College Board, AP ${ }^{\circledR}$ Chemistry Guided-Inquiry Experiments: Applying the Science Practices (Teacher Manual) (The College Board, New York, 2013), pp. 6. 